\title{
HYPERTENSION AND RELATED FACTORS AMONG FEMALE STUDENTS AT VOCATIONAL HIGH SCHOOL BEKASI, INDONESIA
}

\author{
Muh. Nur Hasan Syah" ${ }^{*}$, Utami Wahyuningsih ${ }^{1}$, Sandy Ardiansyah ${ }^{2,4}$, Muhammad Asrullah ${ }^{3}$ \\ ${ }^{1}$ Nutrition Study Program, Faculty of Health Sciences, Universitas Pembangunan Nasional Veteran Jakarta, Indonesia \\ ${ }^{2}$ School of Nutrition and Health Sciences, College of Nutrition, Taipei Medical University, Taiwan \\ ${ }^{3}$ Division of Human Nutrition, Wageningen University and Research, Wageningen, Netherland \\ ${ }^{4}$ Nutrition Departement, Health Polytechnic of Bengkulu, Bengkulu \\ E-mail: mnhasansyah@upnvj.ac.id
}

\begin{abstract}
Hypertension is one of non-communicable diseases which prevalence is high in Indonesia, not only among adult and elderly but also among adolescent. Hypertension can be caused by various factors including fat intake, fiber intake and nutritional status. The purpose of this study was analyze the correlation of fat intake, fiber intake, and obesity with hypertension among female students at Vocational high school, Bekasi, Indonesia. This was a cross sectional study among 255 female students who were selected by purposive sampling technique. Hypertension was measured using sphygmomanometer with 95 percentile cut-off based on sex, age, and body height (cut-off hypertension was > 104-115 mmHg systolic and > 62-68 mmHg diastolic blood pressure). Fat and fiber intake were assessed using Semi Quantitative Food Frequency Questionnaire (SQ-FFQ), and obesity was measured using digital weighing scales and microtoise. Data were analyzed by chi square test. The results showed that prevalence of female students with low $\mathrm{f}$ fat intake was $58,8 \%$; low fiber intake was $82,0 \%$; obesity was $25,1 \%$; and hypertension was $16,5 \%$. There was a positive correlation between fat intake $(\mathrm{p}=0,011)$ and obesity $(\mathrm{p}<0,01)$ with hypertension but no correlation was found between fiber intake $(p=0,916)$ and hypertension. Fat intake and obesity were related to the hypertension in adolescents. Routine blood pressure checks and restrictions on fat intake are needed to reduce the risk of hypertension in adolescents.
\end{abstract}

Keywords: adolescents, fat intake, fiber intake, hypertension, obesity

\section{INTRODUCTION}

In recent decades, Non-Communicable Diseases (NCD) is the global health problem caused global fatalities at $68 \%$. If it is not properly handled, the estimated mortality rate due to NCD will increase to 52 million by 2030 (Nugent et al., 2018). Hypertension, as known as high blood pressure, with systolic and diastolic pressure above the normal rate (Kumar et al., 2011), is the one of NCDs which has high prevalence in both developed and developing countries. It is prevalent not only among elderly but also among adolescent age which is in line with the trend of other NCDs, overweight and obesity, and inadequate nutrient intake in the age group. Adolescence is the right time to instill healthy eating habits and will have an impact on health in adulthood including prevent non-communicable diseases caused by unhealthy dietary pattern (Wulansari, 2009).

In Indonesia, the results of the Basic Health Research in 2013 showed that the number of people with hypertension were $25.8 \%$ or $65,048,110$ people and increased to $34.1 \%$ in 2018 . According to data from the West Java Provincial Health Office, there were 790,382 people $(2.46 \%$ of the population $\geq 18$ years) with hypertension in 2016. In addition, the prevalence based on Joint National Committee (JNC) VIII, 2013 Indonesian health survey counted hypertension among aged 15-17 years old was $5.3 \%$. The prevalence of hypertension in adolescent female needs to be given more attention because, the prevalence in female tends to be higher $(28.8 \%)$ than male (22.8\%) (Riskesdas, 2013). Therefore, the previous study showed that $11.92 \%$ of the population suffering from hypertension which also showed a greater percentage among women $(11.95 \%)$ compared to men (11.88\%) (West Java Health District Officer, 2018).

Regarding risk factors, excessive fat intake, lack of fiber intake, and obesity had been known as the risk factors of hypertension. Kurnianingtyas 
et al. (2017) found that 52\% of adolescents with excess fat intake had hypertension. Furthermore, Amilia et al. (2014) showed that a relationship between the habit of consuming high fat foods with the prevalence of hypertension. Adolescents who tend to consume high-fat food and reduce consumption of fiber including vegetables and fruits have higher risk of hypertension compared to adolescent with a healthy diet. A study using population data from Central Java province showed that rarely consumed fiber causes higher hypertension prevalence $(27.2 \%)$ among adult groups compared to groups who often consumed fiber foods (23.8\%) (Sadiyah, 2016). The problem of dietary intake imbalance can lead to risk of obesity. On another hand, the previous study in Pekanbaru city showed that adult people with obesity increases the risk of hypertension by 6.47 times (Sapitri et al., 2016). Therefore, the aims of the present study were to investigate the relationship of fat intake, fiber intake, and obesity with the prevalence of hypertension of adolescent female in Bekasi City Vocational High School".

\section{METHODS}

This was an observational analytic research with cross sectional design. The population in this study were female students in Bekasi City Vocational High School $(\mathrm{N}=3808)$. A total of 255 students were recruited as the sample of this study with two side calculation method. Sample was purposively selected using inclusion criteria (female students with $14-18$ years old, BMI >-2 SD, having no significant medical condition, no previous diet program and not consumed drugs) and exclusion criteria (female students with previous hypertension, and not willing to participate). Individuual characteristic data (age, parent's education and occupation). Indivual characteristic data (age, parent's education and occupation) were collected using questionnaire.

The independent variables are fat intake, fiber intake and obesity. The weight of the subjects was measured with digital floor scale, with a precision of up to $100 \mathrm{~g}$ and the height was measured with microtoise with $0.1 \mathrm{~cm}$ precision. BMI was calculated as weight in $\mathrm{kg}$ divided by height in meter squared then classified based ob BMI/age as normal ( $>-2 \mathrm{SD})$ and obese ( $>+1 \mathrm{SD})(\mathrm{WHO}$, 2007).

The fat intake were estimated using Semi Quantitative Food Frequency Questionnaire (SQ-FFQ) included 21 food items for the last 1 month. The result was converted to gram per day intake then classified as less intake $(<80 \% \mathrm{RDA})$, sufficient intake (80 - 110\% RDA), and excess intake ( $>110 \%$ RDA) (Hardinsyah and Tambunan, 2004).

The fiber intake were estimated also using SQFFQ included 18 food items for the last 1 month. The result was converted to gram per day intake then classified as less intake $(<20$ gram per day), sufficient ( $20-30$ gram per day), and excess ( $>30$ gram per day) (Muchtadi, 2009).

Furthermore, the dependent variable is hypertension. Hypertension was measured using digital sphygmomanometer with 95 percentile cut-off based on sex, age, and body height (cut-off hypertension was $>104-115 \mathrm{mmHg}$ systolic and $>62-68 \mathrm{mmHg}$ diastolic blood pressure)

Descriptive statistics were used to describe the variables. Chi-square test were used to analysis the relationship between variables with $\mathrm{p}$-values $<0,05$ were considered to be statistically significant.

\section{RESULTS AND DISCUSSIONS}

\section{Subject Characteristic}

The subject characteristics observed were age, father and mother education level, and occupation. The mean age of the respondents was 16 years ( $\mathrm{SD} \pm 1.04)$, the youngest was 14 years and the oldest was 18 years. Regarding to education level, mostly father (56.1\%) has graduated Senior High School as well as mother (49.8\%). Father's occupation were mostly $(67.1 \%)$ an employee. The main finding of this study was the correlation between hypertension and fat intake, fiber intake and nutritional status (overweight) among female students.

\section{Fat Intake}

Based on the table 1, it can be seen that most of the subject (58.8\%) werw having less fat intake $(<80 \%$ of the RDA) . Mean fat intake was 59.97 gr/day with the lowest intake was $12 \mathrm{gr} /$ day and the 
Table 1. Distribution of Subject According to Fat Adequacy

\begin{tabular}{lcc}
\hline \multicolumn{1}{c}{ Fat Intake } & n & (\%) \\
\hline Less $(<80 \%$ RDA $)$ & 150 & 58.8 \\
Sufficient $(80-110 \%$ RDA $)$ & 45 & 17.7 \\
Excess $(>110 \%$ RDA $)$ & 60 & 23.5 \\
Total & 255 & 100.0 \\
\hline
\end{tabular}

highest was $216 \mathrm{gr} / \mathrm{day}$. Subjects mostly consumed fat source foods including snacks one time in a day with a percentage of $44.7 \%$. Based on the results of the study it can be seen from the 255 subjects studied, $23.5 \%$ of subjects consumed excess fat. This percentage is less than the research conducted by Wulandari (2017) in one of the high school in Sukoharjo Regency, his research obtained 30\% of adolescents who consume excess fat. Meanwhile, another study in Semarang found $17.5 \%$ of adolescents who consumed excess fat, which was less than the results of the study (Putri, 2016). The high fat intake in adolescents is closely related to the socioeconomic factors of the subject as well as unhealthy lifestyles, especially the eating habits of adolescents who often consume high-calorie beverage foods.

\section{Fiber Intake}

Table 2 showed that most of the subjects $(82.0 \%)$ having low fiber intake ( $<20 \mathrm{~g} /$ day). The average fiber intake was $13.6 \mathrm{gr} / \mathrm{day}$, with the lowest was $1 \mathrm{gr} /$ day and the highest intake was $59 \mathrm{gr} /$ day. Most of the subjects consume sources of fiber from vegetables and fruit only once a day by $35.7 \%$. Fiber intake found in our study was greater than previous studies in Semarang which found as many as $67.1 \%$ of adolescents consume less fiber (Claudina et al., 2018). Many factors affect the low fiber intake in adolescents such as the selection of foods that tend to be high in energy

Table 2. Distribution of Subject Based on Fiber Intake

\begin{tabular}{lcc}
\hline \multicolumn{1}{c}{ Fiber Intake } & n & (\%) \\
\hline Less (<20 g / day) & 209 & 82.0 \\
Sufficient (20-30 g / day) & 32 & 12.5 \\
Excess ( $>30$ g / day) & 14 & 5.5 \\
Total & 255 & 100.0 \\
\hline
\end{tabular}

Table 3. Distribution of Subject Based on Nutritional Status

\begin{tabular}{lcc}
\hline \multicolumn{1}{c}{ Nutritional status } & $\mathbf{n}$ & $\mathbf{( \% )}$ \\
\hline Normal & 191 & 74.9 \\
Overweight-Obese & 64 & 25.1 \\
Total & 255 & 100.0 \\
\hline
\end{tabular}

and fat, less fruits and vegetable, lifestyle, and family environment. Latest study on adolescents showed that more $70 \%$ girls insufficient fruits and vegetables consumed (Asna et al., 2019)

\section{Nutritional Status}

Table 3 showed that $25.1 \%$ subjects were overweight-obese. This percentage is higher than the research in Bekasi and Semarang which found $19 \%$ of adolescents who experienced overweight and obesity (Putri, 2016) (Syah et al., 2019). The prevalence of obesity in adolescents is closely related to energy intake, fat, excess carbohydrates, frequency of consumption of fast food, low physical activity, genetic, and the habit of skipping breakfast (Kurdanti et al., 2015).

\section{Blood Pressure}

Table 4 showed that the prevalence of hypertension occurs in 42 students $(16.5 \%)$. This percentage is higher than the research of Kurnianingtyas et al. (2017) who found the prevalence of hypertension by $12 \%$ in adolescents in Semarang. The strength of blood pressure is strongly influenced by activity and many other factors including age and sex, family history, genetics, stress, obesity and lifestyle such as smoking, alcohol consumption, and an unhealthy diet (Wang et al., 2014). The wrong diet, both of the amount and type of food consumed is at high risk of increasing hypertension.

Table 4. Distribution of Subject According to Blood Pressure

\begin{tabular}{lcc}
\hline \multicolumn{1}{c}{ Blood Pressure } & n & (\%) \\
\hline No hypertension & 213 & 83.5 \\
Hypertension & 42 & 16.5 \\
Total & 255 & 100.0 \\
\hline
\end{tabular}


Table 5. Distribution of Subject Frequencies Based on Relationship between Fat Intake and Hypertension

\begin{tabular}{|c|c|c|c|c|c|}
\hline \multirow{3}{*}{ Fat Intake } & \multicolumn{4}{|c|}{ Blood Pressure } & \multirow{3}{*}{ Pvalue } \\
\hline & \multicolumn{2}{|c|}{$\begin{array}{c}\text { No } \\
\text { Hypertension }\end{array}$} & \multicolumn{2}{|c|}{ Hypertension } & \\
\hline & $\mathbf{n}$ & $(\%)$ & $\mathbf{n}$ & $(\%)$ & \\
\hline Less & 133 & 88.7 & 17 & 11.3 & \multirow{4}{*}{0.011} \\
\hline Sufficient & 37 & 82.2 & 8 & 17.8 & \\
\hline Exces & 43 & 71.7 & 17 & 28.3 & \\
\hline Total & 213 & 83,5 & 42 & 16,5 & \\
\hline
\end{tabular}

\section{Correlation of Fat Intake with Hypertension}

Based on table 5 , it can be seen that most of the subjects have less fat intake $(58,8 \%)$. Table 5 showed that among those who have high fat intake, twenty eight percent were suffer from hypertension. Statistical test results obtained $p$ value $=0,011$, it can be concluded that there was a significant relationship between fat intake and hypertension.

The results of this study are in line with the research of Mafaza et al. (2016) which states that fat intake is associated with the prevalence of hypertension. The higher consumption of fatty foods can be the risk of hypertension. High fat consumption can increase levels of fat in the blood and cause the formation of plaque. The plaque will develop into atherosclerosis which results in lower elasticity of blood vessels so that the narrowing of the pressure of coronary blood flow causes blood pressure to rise (Widyaningrum \& Rahmat, 2011). Syahrini et al. (2012) who also proved that there was a significant relationship between the consumption of fatty foods such as fat-based foods and snacks with the prevalence of hypertension. Sargowo \& Andarini (2011) explained the effect of the composition of food intake on the components of metabolic syndrome in adolescents, showed that there was a relationship between the composition of fatty food intake against hypertension.

\section{Correlation of Fiber Intake with Hypertension}

Based on table 6 above, $82.0 \%$ subjects were having less fiber; among those who eat less fiber, $83.7 \%$ were not having hypertension and $16.3 \%$ was having hypertension. Statistical test results obtained $p$ value $=0,916$, means there wass no
Table 6. Distribution of Subject Frequencies Based on Relationship of Fiber Intake and Hypertension

\begin{tabular}{|c|c|c|c|c|c|}
\hline \multirow{3}{*}{ Fiber Intake } & \multicolumn{4}{|c|}{ Blood pressure } & \multirow{3}{*}{ Pvalue } \\
\hline & \multicolumn{2}{|c|}{$\begin{array}{c}\text { No } \\
\text { Hypertension }\end{array}$} & \multicolumn{2}{|c|}{ Hypertension } & \\
\hline & n & $(\%)$ & n & $(\%)$ & \\
\hline Less & 175 & 83.7 & 34 & 16.3 & \multirow{4}{*}{0.916} \\
\hline Enough & 26 & 81.3 & 6 & 18.8 & \\
\hline Over & 12 & 85.7 & 2 & 14.3 & \\
\hline Total & 213 & 83.5 & 42 & 16.5 & \\
\hline
\end{tabular}

significant relationship between fiber intake and hypertension.

This study is in line with research conducted by Listiana \& Rizal (2017) which states there wass no relationship between fiber intake and the prevalence of hypertension. In addition, it is known that fiber is not directly related to a decrease in high blood pressure, but fiber is directly related to cholesterol, where fiber binds bile acids (cholesterol end products) and then excreted with feces. Low fiber intake can cause less stool to excrete bile acids, therefore a lot of cholesterol is reabsorbed from the rest of the bile. As a result, cholesterol circulates in the blood more and accumulates in blood vessels (Sari \& Panunggal, 2013). No correlation found between fiber intake and hypertension was because it is not only fiber intake that can affect blood pressure. Although fiber intake is maintained at 20-30 g/ day, if other triggers are not controlled then the possibility of hypertension can still occur such as genetic factors, age, sex, and race. In addition, the results of this study are also in accordance with research conducted by Indira, where there was no significant relationship between fiber intake with systolic blood and diastolic blood pressure. This was probably due to the presence of other nutrient intake factors such as sodium, fat, magnesium and kalium (Indira, 2013).

\section{Correlation of Obesity with Hypertension}

Based on table 7, prevalence of hypertension was found more in subjects who are overweight and obesity $(31.3 \%)$ compared to those who have normal nutritional status $(11.5 \%)$. Statistical test results using the chi square test obtained $\mathrm{p}<0.05$ means that there was a significant 
Table 7. Distribution of Subject Frequencies Based on Relationships with Hypertension

\begin{tabular}{lccccc}
\hline & \multicolumn{4}{c}{ Blood Pressure } & \\
\cline { 2 - 5 } $\begin{array}{l}\text { Nutritional } \\
\text { Status }\end{array}$ & $\begin{array}{c}\text { No } \\
\text { Hypertension }\end{array}$ & \multicolumn{2}{c}{ Hypertension } & P value \\
\cline { 2 - 5 } & $\mathbf{n}$ & $\mathbf{( \% )}$ & $\mathbf{n}$ & $\mathbf{( \% )}$ & \\
\hline Normal & 169 & 88.5 & 22 & 11.5 & \\
$\begin{array}{l}\text { Overweight- } \\
\text { Obese }\end{array}$ & 44 & 68.8 & 20 & 31.3 & 0.000 \\
Total & 213 & 83.5 & 42 & 16.5 & \\
\hline
\end{tabular}

relationship between obesity and the prevalence of hypertension.

Our results shows a smaller percentage than the study of Kurnianingtyas et al., 2017 who found obese adolescents with hypertension accounted for $94.1 \%$. Salam's research also found $61.5 \%$ of obese adolescents had hypertension, which also found a significant relationship between obesity and the prevalence of hypertension (Salam \& Sulchan, 2009). The results of this study are in line with research conducted by Hidayatullah \& Pratama (2019) which states the relationship between obesity and the prevalence of hypertension in adolescents. Obesity is closely related to an increased risk of hypertension. Obesity can increase the prevalence of hypertension. Fat can cause blockages in blood vessels so that the heart works hard in pumping blood resulting in increased blood pressure. Weight gain also causes the heart rate to increase and reduces the capacity of blood vessels to carry blood so that it can increase blood pressure (Suiraoka, 2012). Again, the results of this study are in line with Ikramullah et al., (2014) which also stated that there was a relationship between systolic blood pressure and distolic blood pressure and obesity.

\section{CONCLUSION}

Base on the study, it may be concluded that fat intake has significant correlation with hypertension on female students. This is also in line with the overweight and obesity has a relationship with hypertension. Monitoring and evaluation in the school, especially on hypertension, fat intake and nutritional status, could be a mandatory regulation.

\section{REFERENCES}

Amilia, A., Munawir, M., \& Suhartatik, S. (2014). Faktor yang berhubungan dengan kejadian hipertensi esensial di ruang rawat inap penyakit dalam RSUD Pangkep. Jurnal Ilmiah Kesehatan Diagnosis, 4(6), 693-700.

Asna, A. F., Perdana, S. M., Amelia, R., \& Syah, M. N. H. (2019). Anemia, Nutritional Status, and Dietary Patterns in Adolescent Girls of Vocational High School Students in Bekasi, Indonesia. Annals of Nutrition and Metabolism (Vol. 75, pp. 280-280).

Dinas Kesehatan Provinsi Jawa Barat. (2018). Profil Kesehatan Provinsi Jawa Barat Tahun 2017. Bandung: Dinas Kesehatan Provinsi Jawa Barat

Claudina, I., Pangestuti, D. R., \& Kartini, A. (2018). Hubungan Asupan Serat Makanan dan Cairan dengan Kejadian Konstipasi Fungsional pada Remaja di SMA Kesatrian 1 Semarang. Jurnal Kesehatan Masyarakat (e-Journal), 6(1), 486-495.

Hardinsyah \& Tambunan, V. 2004. Angka kecukupan energi, protein, lemak dan serat makanan. Prosiding Widyakarya Nasional Pangan dan Gizi VIII, 17-19.

Hidayatullah, M. T., \& Pratama, A. A. (2019). Hubungan Kebiasaan Merokok dan Obesitas dengan Kejadian Hipertensi pada Remaja Usia 15-19 Tahun. Smiknas, 108-115.

Indira, I. N. (2013). Hubungan Antara Asupan Serat dengan Profil Tekanan Darah pada Usia Dewasa di Kecamatan Kedungkandang Kota Malang. (Skripsi, Universitas Brawijaya).

Kumar, R., Cotran, R. S., \& Robbins, S. L. (2011). Buku Ajar Patologi. Volume 2. Edisi 7. Jakarta: EGC.

Kurdanti, W., Suryani, I., Syamsiatun, N. H., Siwi, L. P., Adityanti, M. M., Mustikaningsih, D., \& Sholihah, K. I. (2015). Faktor-faktor yang mempengaruhi kejadian obesitas pada remaja. Jurnal Gizi Klinik Indonesia, 11(4), 179-190.

Kurnianingtyas, B. F., Suyatno, S., \& Kartasurya, M. I. (2017). Faktor Risiko kejadian hipertensi pada siswa sma di kota semarang Tahun 2016. Jurnal Kesehatan Masyarakat (e-Journal), 5(2), 70-77.

Listiana, L., \& Rizal, A. K. A. (2017). Hubungan pola konsumsi zat gizi makro dan mikro dengan tekanan darah pada penderita hipertensi. Jurnal Media Kesehatan, 10(2), 126-138. 
Mafaza, R. L., Wirjatmadi, B., \& Adriani, M. (2016). Analisis hubungan antara lingkar perut, asupan lemak, dan rasio asupan kalsium magnesium dengan hipertensi. Media Gizi Indonesia, 11(2), 127-134.

Salam, M. A., \& Sulchan, M. (2009). Risiko Faktor Hereditas, Obesitas dan Asupan Natrium Terhadap Kejadian Hipertensi pada Remaja Awal. Journal of Nutrition Collage, 1(1), $1-14$

Muchtadi, D. (2009) Pengantar Ilmu Gizi. Bandung: Alfabeta.

Nugent, R., Bertram, M. Y., Jan, S., Niessen, L. W., Sassi, F., Jamison, D. T., Pier, E. G., \& Beaglehole, R. (2018). Investing in non-communicable disease prevention and management to advance the Sustainable Development Goals. The Lancet, 391(10134), 2029-2035.

Putri, L. P. (2016). Hubungan Densitas Energi Dan Asupan Zat Gizi Makro Dengan Kejadian Sindrom Metabolik Pada Remaja Obesitas. Journal of Nutrition College, 5(3), 214-221

Sadiyah, E. R. (2016). Faktor-Faktor Yang Berhubungan Dengan Hipertensi Pada Orang Dewasa Di Propinsi Jawa Tengah (Analisis Data Riskesdas Tahun 2007). Prosiding SNaPP: Kesehatan (Kedokteran, Kebidanan, Keperawatan, Farmasi, Psikologi), 2(1), 19-27.

Sapitri, N., Suyanto, \& Butar-butar, W. R. (2016). Analisis faktor risiko kejadian hipertensi pada masyarakat di pesisir sungai siak kecamatan rumbai kota pekanbaru. Jom $F K, 3(1), 1-15$.

Sargowo, D., \& Andarini, S. (2011). Pengaruh komposisi asupan makan terhadap komponen sindrom metabolik pada remaja. Jurnal Kardiologi Indonesia, 32(1), 14-23.

Sari, D. M., \& Panunggal, B. (2013). Hubungan Asupan Serat, Natrium dan Aktivitas Fisik terhadap Kejadian Obesitas dengan Hipertensi pada Anak Sekolah Dasar. Journal of Nutrition College, 2(4), 467-473.

Suiraoka, I. P. (2012). Penyakit Degeneratif. Yogyakarta: Nuha Medika.

Syah, M. N. H., Asna, A. F., \& Wahono, D. N. (2019). Irregular Weight Monitoring Associated With Overweight-Obesity In Adolescent (High School Student) at Bekasi. In Annals of Nutrition and Metabolism (Vol. 75, pp. 133-134).

Syahrini, E. N., Susanto, H. S., \& Udiyono, A. (2012). Faktor-faktor risiko hipertensi primer di puskesmas Tlogosari Kulon Kota Semarang. Jurnal Kesehatan Masyarakat Universitas Diponegoro, 1(2), 315-325.

Ikramullah, Qureshi, M. S., Hadi, A., Khan, S. B., \& Hafizullah, M. (2014). Correlation of body mass index with frequency of high blood pressure. Pak Heart J, 47(1), 46-50.

Wang, F., Tiwari, V. K., \& Wang, H. (2014). Risk factors for hypertension in india and china: A comparative study. Health and PopulationPerspectives and Issues, 37(1), 40-49.

Widyaningrum, H., \& Rahmat, A. (2011). Kitab Tanaman Obat Nusantara. Yogyakarta: Media Pressindo.

Wulandari, D. T. (2017). Hubungan Antara Karbohidrat dan Lemak dengan Kejadian Overweight pada Remaja di SMA Muhammadiyah 4 Kartasura Kabupaten Sukoharjo. Jurnal Riset Kesehatan Poltekkes Depkes Bandung, 9(1), 53-63.

Wulansari, N. D. (2009). Konsumsi serta Preferensi Buah dan Sayur pada Remaja SMA dengan Status Sosial Ekonomi yang Berbeda di Bogor. (Skripsi, Institut Pertanian Bogor).

World Health Organization. (2007). The world health report 2007: a safer future: global public health security in the 21st century. World Health Organization 